\title{
Effect of Proteins from the Red Seaweed Hypnea musciformis (Wulfen) Lamouroux on the Growth of Human Pathogen Yeasts
}

\author{
Rossana Aguiar Cordeiro ${ }^{1}$, Valdirene Moreira Gomes ${ }^{2}$, Ana Fontenele Urano Carvalho ${ }^{1}$ \\ and Vânia Maria Maciel Melo ${ }^{1 *}$ \\ ${ }^{1}$ Departamento de Biologia; Universidade Federal do Ceará; 60451-970; Fortaleza - CE - Brasil. ${ }^{2}$ Centro de \\ Biociências e Biotecnologia; Universidade Estadual do Norte Fluminense; 28013-600; vmmmelo@ufc.br; Campos \\ dos Goytacazes - RJ - Brasil
}

\begin{abstract}
A protein fraction, rich in lectin, obtained from the red seaweed Hypnea musciformis by precipitation with ammonium sulfate $\left(F_{40 / 70}\right)$ was screened for chitinase and $\beta$-1,3-glucanase activity and assessed for antifungal potential against the human pathogen yeasts Candida albicans and $\mathrm{C}$. guilliermondii. The $F_{40 / 70}$ fraction showed chitinase and $\beta$-1,3-glucanase enzymes, with specific activities of 276.43 and 1880.7 Units.mg ${ }^{-1}$ protein, respectively. It was capable of inhibiting the growth of $\mathrm{C}$. guilliermondii at the concentrations of 45,100 and 450 $\mu g$ protein.ml ${ }^{-1}$ but it showed only a discrete inhibition against $C$. albicans irrespective of the tested concentrations. The inhibitory action was shown to be fungistatic and the presence of the glycoprotein fetuin, for which the lectin in the fraction had affinity, abolished the antifungal action. The complete growth recovery following fetuin treatment indicated that chitinase and $\beta$-1,3-glucanase were not involved in the growth inhibition of these yeasts.
\end{abstract}

Key words: Hypnea musciformis, antifungal activity, $\beta$-1,3-glucanase, chitinase, lectin

\section{INTRODUCTION}

Seaweeds represent a potential source of antimicrobial substances due to their diversity of secondary metabolites with antiviral, antibacterial and antifungal activities (Caccamesse et al., 1980; Del Val et al., 2001; Perry et al., 1991). The antibacterial activity of seaweeds is generally assayed using extracts in various organic solvents, e.g., acetone, methanol-toluene, ether and chloroform-methanol. Several extractable compounds, such as cyclic polysulfides and halogenated compounds are toxic to microorganisms and, therefore, responsible for the antibiotic activity of some seaweeds (Fenical, 1975; Wrattens and Faulkner, 1976). Similarly seaweeds are known for their protein diversity i.e. lectins, hexose oxidase, bromoperoxidase, chitinase, etc (Groen et al., 1997; Krenn et al., 1989; Rogers and Hori, 1993; Sekiguchi et al., 1995) but little attention has been given to their potential as antimicrobial agents.

Previously we demonstrated that a protein fraction, rich in lectin, from the red seaweed Hypnea musciformis was able to inhibit the growth of the dermatophyte Trichophyton rubrum and the

${ }^{*}$ Author for correspondence 
phytopathogen Colletotrichum lindemuthianum (Melo et al., 1997), and more recently Liao et al. (2003) showed antibiotic activity of seaweed lectins against two species of marine bacteria. Lectins are proteins that interact with various cellular structures, particularly cell walls and cell membranes, through which they can trigger several biological effects including agglutination of erythrocytes (Peumans and Van Damme, 1995). Since the report of Boyd et al. (1966), numerous studies have indicated the presence of lectins in seaweeds (Hori et al., 1986; Rogers and Hori 1993).

Although many activities have been attributed to seaweed lectins their physiological function has not been clearly proven. The glucan hydrolases, such as chitinases and $\beta-1,3$-glucanases are truly recognized as natural antifungical proteins widely found in plants (Shewry and Lucas, 1997) and seaweeds (Sekiguchi et al., 1995). Chitinases can hydrolyze chitin, a linear polymer of $\beta$-1,4-linked $\mathrm{N}$-acetyl glucosamine found in insect exoskeleton, shells of crustaceans and fungal cell walls, and structural component of the cells walls of many seaweeds (Pearlmutter and Lembi, 1978). B-1,3glucanases are well characterized in fungi, bacteria, plants and in echinodermata and it is well known that they could be related to autocatalysis of extracellular matrix glucans (fungi), digestion of cell walls (bacteria), and as inducible defense enzymes in plants (Stintzi et al., 1993) against fungal pathogens that contain $\beta$-glucans within their cell walls. $H$. musciformis is one of the most abundant source of $\kappa$-carrageenan in Brazil, occurring from $4^{\circ} \mathrm{S}, 37^{\circ} \mathrm{W}$ to $29^{\circ} \mathrm{S}, 49^{\circ} \mathrm{W}$ (Schenkman, 1989). As the species is widespread on the coast and the best areas for exploitation are in northeastern Brazil (Oliveira-Filho, 1981), there is a good prospect for exploitation in the whole country.

Given the economic potential of this seaweed and the importance of $\beta$-1,3-glucanase and chitinase as potential determinants in the resistance of plants to fungal diseases ( $\mathrm{Ji}$ and Kuc, 1996), the presence of these proteins in the lectin-rich fraction obtained from the red seaweed $H$. musciformis was analyzed and the activity against the human pathogen yeasts Candida albicans and $C$. guilliermondii was assessed.

\section{MATERIALS AND METHODS}

\section{Seaweed}

Specimens of $H$. musciformis were collected from the northeastern Brazilian coast (Flexeiras Beach, Trairi, Ceará, Brazil), brought to the laboratory in water-ice bags, washed with distilled water and kept at $-20^{\circ} \mathrm{C}$ until use.

\section{Reagents}

Bovine serum albumin, fetuin, laminarin and methylumbelliferyl-beta-N,N',N"'-

triacetylchitotriose (4-MU(GlcNAc $\left.)_{3}\right)$ were purchased from Sigma (St. Louis, MO, USA). Sabouraud agar and Malt extract broth were from Merck (Darmstadt, Germany). All other chemicals used were of analytical grade.

\section{Microorganisms and culture methods}

Strains of $C$. albicans and C. guilliermondii isolated from patients with recurrent vulvovaginal candidiasis were kindly provided by Dr Julio Sidrim, "Centro Especializado em Micologia Médica" (Federal University of Ceará, Brazil). Stock cultures were maintained in Sabouraud agar at $4^{\circ} \mathrm{C}$.

\section{Preparation of $\boldsymbol{F}_{40 / 70}$ ammonium sulfate fraction}

For the preparation of $\mathrm{F}_{40 / 70}$ fraction from $H$. musciformis, a previously described method (Melo et al., 1997) was used. The seaweeds were thawed, dehydrated at $30{ }^{\circ} \mathrm{C}$ and ground to a fine powder with an electric mill and stirred for $12 \mathrm{~h}$ with phosphate buffered saline [(PBS) $25 \mathrm{mM}$ Sodium Phosphate, $0.15 \mathrm{M} \mathrm{NaCl}, \mathrm{pH} 7.0]$. The extract was filtered through nylon cloth and centrifuged at $7,000 \mathrm{~g}$ for $15 \mathrm{~min}$ at $4{ }^{\circ} \mathrm{C}$. The supernatant was treated with ammonium sulfate from 40 to $70 \%$ and the precipitated proteins were centrifuged, resuspended in distilled water, dialyzed, lyophilized and stored at $-20^{\circ} \mathrm{C}$ until use for protein determination (Bradford, 1976), antifungal, enzymatic and agglutination assays.

\section{Evaluation of antimicrobial activity}

Antifungal activity was assessed following turbidity of yeast cultures along the time. Stock solutions of $\mathrm{F}_{40 / 70}$ fraction were sterilized using a $0.22 \mu \mathrm{m}$ membrane (Millipore, USA) and were diluted with equal volume of sterilized Malt Extract broth to obtain the final concentrations of $10,45,100$ and $450 \mu \mathrm{g}$ protein.ml ${ }^{-1}$. For the assay, 
the yeast cells were obtained by centrifugation at $4,000 \mathrm{~g}$ for $10 \mathrm{~min}$ from $48 \mathrm{~h}$ culture grown in Malt broth at $28{ }^{\circ} \mathrm{C}$. Cells were quantified in a Neubauer chamber and the working suspension of the inoculum adjusted to $4 \times 10^{4} \mathrm{cfu}^{\mathrm{mL}} \mathrm{m}^{-1} .100 \mu \mathrm{l}$ of the cell suspensions were incubated in 96-wells flat microplates (Nunc ${ }^{\mathrm{TM}}$, Denmark) with the same volume of the protein fraction. The microplates were incubated without agitation at $25^{\circ} \mathrm{C}$ and yeast growth was followed for $48 \mathrm{~h}$ by measuring absorbance at $520 \mathrm{~nm}$ every $12 \mathrm{~h}$. All the experiments were run in triplicate and the reading averages, standard errors and coefficients of variation were calculated. Control wells (inoculum suspension in malt extract broth without $\mathrm{F}_{40 / 70}$ fraction) were included for each isolate tested. One well containing $200 \mu \mathrm{l}$ of culture medium was included as sterility control.

\section{Hemagglutination and hemagglutination inhibition tests}

Hemagglutination tests were performed according to Moreira and Perrone (1977) using $2 \%$ tripsintreated rabbit erythrocytes suspended in PBS. Hemagglutination-inhibition was evaluated by method described by Melo et al. (2000) using fetuin at the starting concentration of $6 \mathrm{mg} \cdot \mathrm{mL}^{-1}$. Agglutination was observed macroscopically and the titer expressed as hemagglutinating unit (HU), which was defined as the inverse of the highest dilution still capable of causing visible agglutination.

\section{Enzymatic Assays}

Chitinase activity was determined according to the method of O'Brien and Colwell, (1987) using the fluorogenic substrate 4-methylumbelliferyl- $\beta$ N,N',N"triacetylchitotriose (4-MU (GlcNAc) $)_{3}$ ). Free 4-methylumbelliferone (4-MU) was measured fluorimetrically with $320 \mathrm{~nm}$ primary and $460 \mathrm{~nm}$ secondary filters in a Hitach F4500 fluorescence spectrophotometer. A standard curve was set up to show the relationship between the measured fluorescence units (fu) and the increasing amounts of free 4-MU (O'Brien and Colwell, 1987). One unit of enzyme activity was reported as one nmol of methylumbeliferone liberated per min. The $\beta$-1,3-glucanase activity was assayed according to methodology which employs laminarin as substrate (Fink et al., 1988). The absorbance was read at $500 \mathrm{~nm}$ after addition of copper and arsenomolibdate reagents (Nelson
1944; Somogyi, 1952). One unit of $\beta-1,3-$ glucanase (GU) activity was defined as the concentration of enzyme which produces an absorbance increase of 0.001 .

\section{RESULTS}

Samples of $\mathrm{F}_{40 / 70}$ fraction showed a protein content of $143 \mu \mathrm{g} \cdot \mathrm{mg}^{-1}$ with hemagglutination titer of 128 HU.mg ${ }^{-1}$ protein only in trypsin-treated rabbit erythrocytes. Assays of enzymatic activities showed that $\mathrm{F}_{40 / 70}$ fraction contained chitinase and $\beta$-1,3-glucanase, with specific activity of 276.43 and 1880.7 Units.mg ${ }^{-1}$ protein, respectively.The growth patterns of $C$. guilliermondii and $C$. albicans at the presence of $\mathrm{F}_{40 / 70}$ fraction are shown in Figures 1 and 2, respectively.

The $\mathrm{F}_{40 / 70}$ fraction inhibited the growth of both yeasts at the concentrations of 45,100 and $450 \mu \mathrm{g}$ protein. $\mathrm{mL}^{-1}$. Nevertheless $C$. guilliermondii was more susceptible than $C$. albicans with growth inhibition lasting for up to $36 \mathrm{~h}$ irrespective of the concentrations. At the lowest dose $(10 \mu \mathrm{g}$ protein. $\mathrm{mL}^{-1}$ ), no reduction effect was observed for either the yeasts. On the other hand, the other doses showed similar inhibitory effect against $C$. albicans whereas the effect was dose-dependent against $C$. guilliermondii.

As an attempt to identify whether the lectin was involved in the inhibitory effect on yeast growth, the lectin was previously treated with its specific hapten fetuin and the antimicrobial assay redone. The results showed that the growth of both yeasts could occur just after inoculation similarly as the control or even better (Figures 3 and 4).

\section{DISCUSSION}

The $\mathrm{F}_{40-70}$ from the red seaweed $H$. musciformis containing lectin and glucan hydrolases such as chitinase and $\beta$-1,3-glucanase was shown to have antifungal activity against $C$. albicans and $C$. guilliermondii. To our knowledge there has been only one work reporting the detection of chitinolytic activity in seaweeds (Sekiguchi et al., 1995), suggesting chitinase activity in 30 out of 57 species of Rhodophyta, one of 28 species of Phaeophyta and absent in all 13 species of Chlorophyta. Among the Rhodophyta Chondrus giganteus showed the highest activity $\left(53 \mathrm{nmol.g}{ }^{-1}\right)$ 
whereas Hypnea charoides and H. japonica showed a moderate activity (16 and 12 nmol. $\mathrm{g}^{-1}$, respectively). The present paper described for the first time the detection of glucanase activity in seaweeds and presented chitinase activity in another species of Hypnea. Although glucan hydrolases were well recognized as pathogenesis related proteins (Shewry and Lucas 1997), the total growth recovery of yeasts after treating the fraction $\mathrm{F}_{40 / 70}$ with fetuin indicated that the lectin was the main or the only fraction component responsible for growth inhibition of these yeasts. It was likely that the higher susceptibility of $C$. guilliermondii to the lectin could be due to the presence of more receptors or easier access of this protein to yeast cell surface. Lectin or lectin-like substances in seaweeds have also been shown to bind selectively to different microorganisms suggesting they could be excellent tools in taxonomic and diagnostic studies (Criado and Ferreiros, 1983; Fabregas et al., 1989).

Lectins in higher plants defend against pathogenic bacteria and fungi by recognizing and immobilizing the infecting microorganisms via binding, thereby preventing their subsequent growth and multiplication (Etzler, 1986). Lectins from bivalves and other invertebrates act in a similar manner to eliminate invading pathogenic bacteria (Kilpatrick, 2002). This type of defense mechanism is not completely clear in seaweeds, mainly due to the limited number of lectins available from these organisms and the small amounts present.

Nevertheless, lectins from seaweeds appear to aggregate fungi, bacteria, blue-green algae, as well as erythrocytes (Boyd et al., 1966; Criado and Ferreiros, 1983; Hori et al., 1986; Hori et al.,1996) and some do impair microorganisms development (Melo et al., 1997, Liao et al., 2003). Thus, seaweed lectins as plant lectins may be involved in defence mechanisms against pathogens.

It could be concluded that the protein fraction $\left(\mathrm{F}_{40 / 70}\right)$ from the red seaweed $H$. musciformis inhibited the growth of the human pathogens $C$. guilliermondii and $C$. albicans. The antifungal activity appeared to be due to the lectin component and not due to chitinase and $\beta$-1,3-glucanase.

Further studies on the mechanism of action of this lectin on yeast growth would be necessary so that its utilization for medicinal use could be evaluated. Thus, the seaweed H. musciformis represented a promising source of antimicrobial substance besides its well-known value as a $\kappa$-carrageenan source.

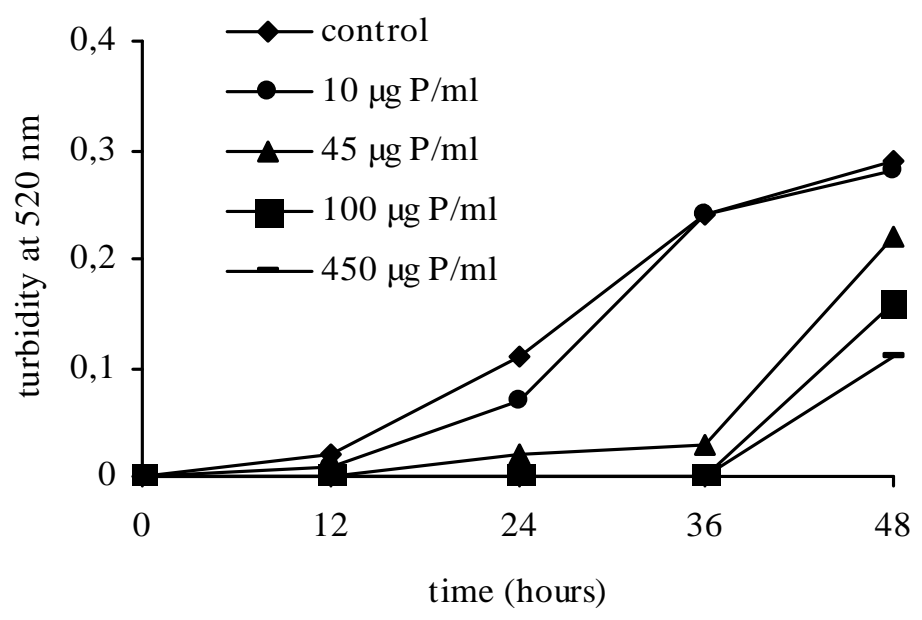

Figure 1 - Effect of $\mathrm{F}_{40 / 70}$ fraction from Hypnea musciformis on Candida guilliermondii growth. Experiments were run in triplicate and the standard errors (coefficients of variation were less than $20 \%$ ) were omitted for clarity. 


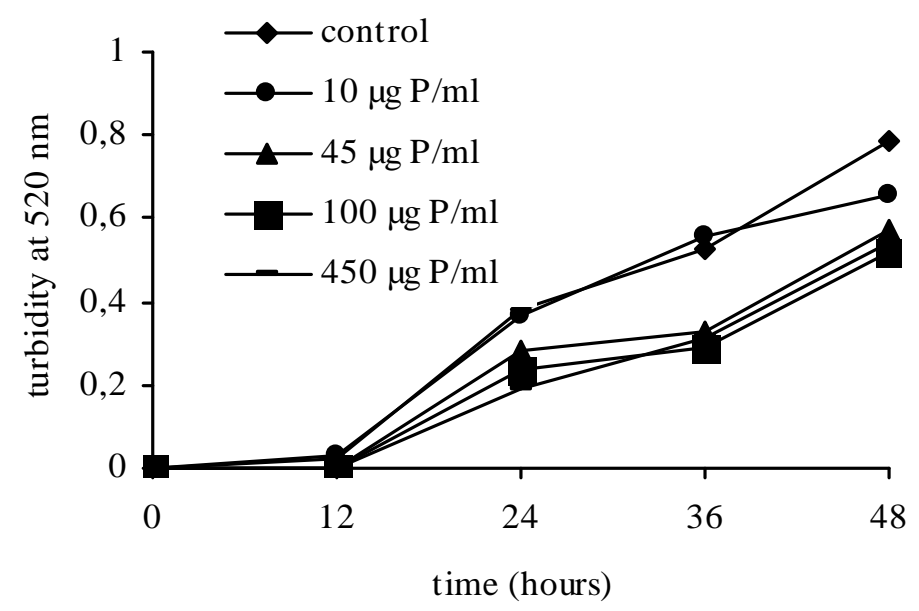

Figure 2 - Effect of $\mathrm{F}_{40 / 70}$ fraction from Hypnea musciformis on Candida albicans growth. Experiments were run in triplicate and the standard errors (coefficients of variation were less than $20 \%$ ) were omitted for clarity.

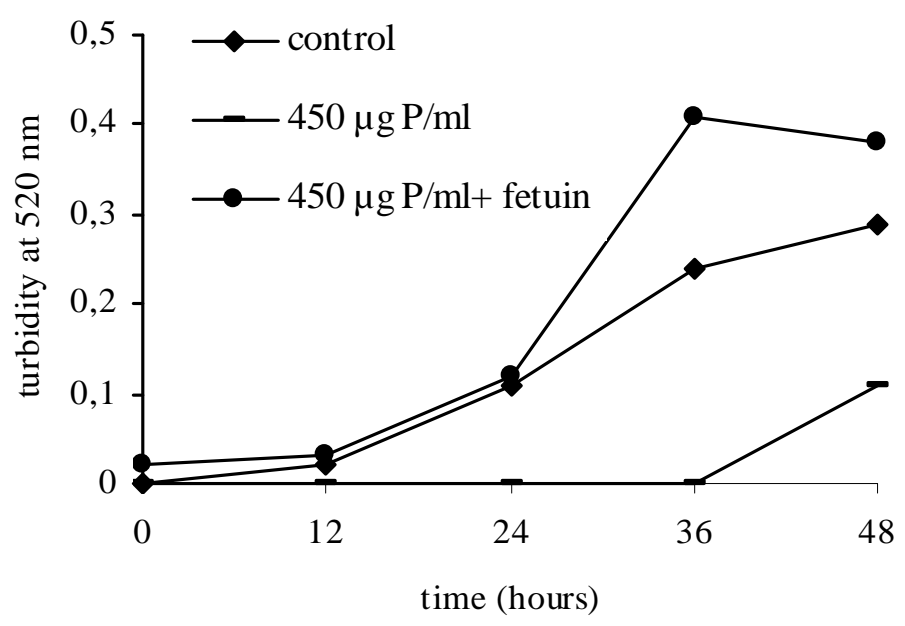

Figure 3 - Effect of $\mathrm{F}_{40 / 70}$ fraction from Hypnea musciformis treated with fetuin on Candida guilliermondii growth. Experiments were run in triplicate and the standard errors (coefficients of variation were less than $20 \%$ ) were omitted for clarity. 


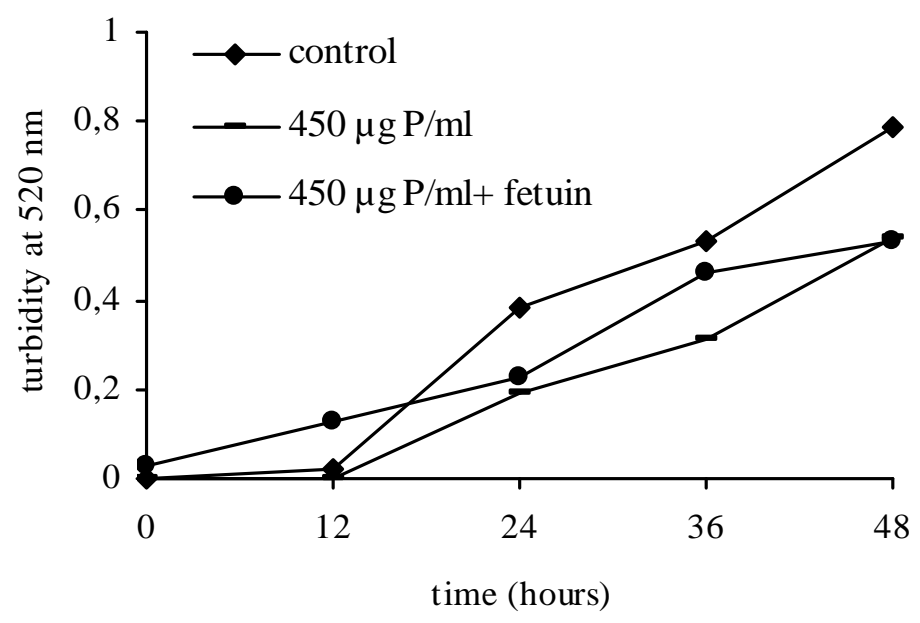

Figure 4 - Effect of $\mathrm{F}_{40 / 70}$ fraction from Hypnea musciformis treated with fetuin on Candida albicans growth. Experiments were run in triplicate and the standard errors (coefficients of variation were less than $20 \%$ ) were omitted for clarity.

\section{ACKNOWLEDGEMENT}

This work was supported by CNPq

\section{RESUMO}

Uma fração protéica, rica em lectina, obtida por precipitação com sulfato de amônia $\left(\mathrm{F}_{40 / 70}\right)$, da alga marinha vermelha Hypnea musciformis foi avaliada quanto à presença de atividade quitinásica e $\beta$-1,3-glucanásica e potencial antifúngico contra as leveduras patogênicas Candida albicans e $C$. guilliermondii. A fração $\mathrm{F}_{40 / 70}$ mostrou ambas as atividades enzimáticas, com atividades específicas de 276,43 e 1880,7 Unidades.mg ${ }^{-1}$ proteína, respectivamente. Essa fração foi capaz de inibir de forma significativa o crescimento da levedura $C$. guilliermondii nas concentrações de 45, 100 e 450 $\mu \mathrm{g}$ proteína.ml ${ }^{-1}$ porém mostrou apenas uma discreta ação contra $C$. albicans, independente das concentrações testadas. A ação inibitória foi fungistática e a presença da glicoproteína fetuína, para a qual a lectina na fração tem afinidade, aboliu a ação antifúngica. A recuperação completa do crescimento das leveduras após tratamento com fetuína indicou que as atividades quitinásica e $\beta$ 1,3-glucanásica não estão envolvidas na inibição do crescimento dessas leveduras.

\section{REFERENCES}

Boyd, W. C.; Almodovar, L. R. and Boyd, L. G. (1966), Agglutinin in marine algae for human erythrocytes. Transfusion, 6: (1), 82-83.

Bradford, M. M. (1976), A rapid and sensitive method for the quantitation of microgram quantities of protein utilizing the principle of dye binding. Anal Biochem., 72, 248-254.

Caccamese, S.; Azoolina, R.; Fumari, G.; Cormaci, M. and Grasso, S. (1980), Antimicrobial and antiviral activities of extracts from Mediterranean algae. Bot Mar., 23, 285-288.

Criado, M. T. and Ferreiros, C. M. (1983), Selective interaction of a Fucus vesiculosus lectin-like mucopolysaccharide with several Candida species. Ann Microbiol., 134A, 149-154.

Del Val, A. G.; Platas, G.; Basílio, A.; Cabello, A.; Gorrochategui, J.; Suay, I.; Vicente, F.; Portillo, E.; del Río, M. J.; Reina, G. G. and Peláez, F. (2001), Screening of antimicrobial activities in red, green and brown macroalgae from Gran Canaria (Canary Islands, Spain). Int Microbiol., 4, 35-40.

Etzler, M. E. (1986), Distribution and function of plant lectins. In: Liener, I. E.; Sharon, N. and Goldstein, I. J. (Eds). The lectins. Properties, function, and applications in biology and medicine. Orlando, Florida: Academic. pp. 371-435.

Fabregas, J.; Munoz, A.; Llovo, J. and Carracedo, A. (1988), Tometine: a lectin for the detection of glycoprotein polymorphisms. Med Sci Res., 16, 819-820.

Fenical, W. (1975), Halogenation in the Rhodophyta. A review. J. Phycol., 11, 245-259. 
Fink, W.; Liefland, M. and Mendgen, K. (1988), Chitinases and $\beta$-1,3-glucanases in the apoplastic compartment of oat leaves (Avena sativa L.). Plant Physiol., 88, 270-275.

Groen, B. W.; De Vries, S. and Duine, J. A. (1997), Characterization of hexose oxidase from the red seaweed Chondrus crispus. Eur. J. Biochem., 244: (3), 858-861.

Hori, K.; Miyazawa, K. and Ito, K. (1986), Preliminary characterization of agglutinins from seven marine algal species. Bull. Jap. Soc. Fish., 52, 323-331.

Hori, K.; Ogata, T.; Kamiya, H. and Mimuro, M. (1996), Lectin-like compounds and lectin receptors in marine microalgae: hemagglutination and reactivity with purified lectins. J. Phycol., 32,783-790.

Ji, C. and Kuc, J. (1996), Antifungal activity of cucumber $\beta$-1,3-glucanase and chitinase, Physiol. Mol Plant Pathol., 49, 257-265.

Kilpatrick, D. C. (2002), Animal lectins: a historical introduction and overview. Biochim. Biophys. Acta, 1572, 187-197.

Krenn, B. E.; Tromp, M. G. and Wever, R. (1989), The brown alga Ascophyilum nodosum contains two different vanadium bromoperoxidases. J. Biol. Chem., 264: (32), 19287-19292.

Liao, W. R.; Lin, J. Y.; Shieh, W. Y.; Jeng, W. L. and Huang, R. (2003), Antibiotic activity of lectins from marine algae against marine vibrios. J. Int. Microbiol. Biotechnol., 30,433-439.

Melo, V. M. M.; Medeiros, D. A.; Rios, F. J. B.; Castelar, L. I. M. and Carvalho, A. F. F. U. (1997), Antifungal properties of proteins (agglutinins) from the red alga Hypnea musciformis (Wulfen) Lamouroux. Bot Mar., 40, 281-284.

Melo, V. M. M.; Duarte, A. B. G.; Carvalho, A. F. F. U.; Siebra, E. A. and Vasconcelos, I. M. (2000), Purification of a novel antibiotic and haemagglutinating protein from the purple gland of the sea hare Aplysia dactylomela Rang 1828. Toxicon., 38: (10), 1415-1427.

Moreira, R. A. and Perrone, J. C. (1977), Purification and partial characterization of a lectin from Phaseolus vulgaris. Plant Physiol., 56, 783-787.

Nelson, N. (1944), A photometric adaptation of the Somogyi method for the determination of glucose. $J$ Biol Chem., 153, 375-380.
O'Brien, M. and Colwell, R. R. (1987), A rapid test for chitinase activity that uses 4-methylumbelliferyl-Nacetyl-beta- D-glucosamide. Appl Environ Microbiol., 53,1718-1720.

Oliveira-Filho, E. C. (1981), A exploração de algas marinhas no Brasil: situação atual e perspectivas futuras. Phycol. Lat. Amer., 1, 5-18.

Pearlmutter, N. L. and Lembi, C. A. (1978), Localization of chitin in algal and fungal cell walls by light and electron microscopy. J. Histochem Cytochem., 26: (10), 782-791.

Perry, N. B.; Blunt, J. W. and Munro, M. H. (1991), A cytotoxic and antifungal 1,4-naphthoquinone and related compounds from a New Zealand brown algae, Landsburgia quercifolia. J Nat Prod., 54: (4), 978-985.

Peumans, W. J. and Van Damme, E. J. M. (1995), Lectins as plant defense proteins. Plant Physiol., 109, 347-352.

Rogers, D. J. and Hori, K. (1993), Marine algal lectins New developments. Hydrobiol., 261, 589-593.

Schenkman, R. P. F. (1989), Hypnea musciformis (Rhodophyta). Ecological influence on growth. $J$. Phycol., 25,192-196.

Sekiguchi, J.; Matsumiya, M.; Mochizuki, A. (1995), Distribution of chitinolytic enzymes in seaweeds. Fish Sci., 61: (5), 876-881.

Shewry, P. R. and Lucas, J. A. (1997), Plant proteins that confer resistance to pest and pathogens. Adv. Bot. Res., 26, 135-192.

Somogyi, M. (1952), Notes on sugar determination. $J$. Biol. Chem., 195, 19-23.

Stintzi, A.; Heitz, T.; Plasad, V.; WiedemannMerdinoglu, S.; Kauffman, S.; Geoffroy, P.; Legrand, M. and Fritig, B. (1993), Plant pathogenesis-related proteins and their role in defence against pathogens. Biochim., 75, 687-706.

Wrattens, J. and Faulkner, D. J. (1976), Cyclic polysulfides from the red alga Chondrus californica. J. Org. Chem., 41, 2465-2467.

Received: May 06, 2005; Revised: November 08, 2005; Accepted: July 25, 2006. 